\title{
Unlocking the Cult of Early-Stage High-Tech Startup Founders
}

\author{
Priyanka Botny Srinath \\ Edinburgh Business School, Heriot-Watt University, Edinburgh, UK \\ *Correspondence: Priyanka Botny Srinath ; Email: botny.priyanka@gmail.com ; ORCID: 0000-0002-1050-9957
}

\begin{abstract}
In this paper, we unlock the cult of high-tech startup founders by taking a sample case study and observing various early-stage founders. Performing ethnographic studies has pointed us in the direction to use patents as a qualifier for technological credibility which serves as an inspiration to such startup founders. When the newbie startup founders are seeking funding, they need to define traits of the success laid out by top high-tech companies that were once startups. We observed 300 early-stage high-tech startup founders around the world, while some of them were in college, some quit college and others start after getting substantial work experience. The high-tech startup world is full of innovative ideas to solve big problems and introduce the workable tech solution to their respective markets. We performed a case study of an early-stage startup that won an innovation challenge and how they struggled to reach credibility and revenue success. Overall, we define this outcome as a cult among the early-stage high-tech startup founders while unlocking revenue success, patenting to scale innovation and human element.
\end{abstract}

Keywords: High-tech innovation, Startups, Patents, Cult

General Terms: Founders, Market, Brand, Revenue, Value, Product

\section{ARTICLE INFORMATION}

Author(s): Priyanka Botny Srinath

Received: 26 Jan, 2021; Accepted: 11 Mar, 2021; Published: 19 Mar, 2021; e-ISSN: 2347-4696;

Paper Id: BMN-IJBMR-2021-11;

Citation: doi.org/10.37391/IJBMR.090112

Webpage-link:

https://ijbmr.forexjournal.co.in/archive/volume-9/ijbmr-090112.html

\section{INTRODUCTION}

According to Crunchbase data collection on the various hightech companies that have registered patents, IBM holds the highest number of patents followed by Microsoft, Seimens and Apple. Each of these high-tech companies have 30,000+ patents. These companies were once started small and some of these were high-tech startups. In the paper, we wish to define a successful high-tech startup as the one that has high revenue and high number of patents which forms a guidance basis for early-stage high-tech founders to follow some traits and aim for success path. The company runs research and development activity and combines the features of an innovative and knowledge-based company. It uses to a large extent modern information technology and is open to cooperation with environment, creating various network connections and clusters with other organizations. A high technology company defined in this way has certain characteristics, which are quite different than a traditional production or service enterprise [1]. The importance of this paper is to unlock the cult of an earlystage high-tech startup founder where these founders hail from various backgrounds which primarily include their work experience gained at larger high-tech companies when they were once a manager which helped them gain key entrepreneurial skills that shows high success rates in overall job performance in terms of revenue and innovativeness [2, 3,
4].

\section{? 2. EARLY-STAGE HIGH-TECH STARTUP FOUNDER}

After closely observing 300 early-stage high-tech startups founders over a period of 10 years from across the globe, we have identified that passionate teams have invested a lot of time and effort into building innovation via $R \& D$. In order to protect the rights of innovation and to avoid replication, patents are a great way to save the intellectual property. These innovators hail from college, drop out of college or gain work experience and start innovating great ideas to IPO. It has become a cult to innovate and test their ideas in the market. But these startup founders lack the infrastructure to scale. How can we provide them with success roadmap to still grow revenue and continue to innovate? Can patents help them scale faster? These are the two questions we are covering in this paper a gold standard measure for early-stage high-tech startup founders to follow.

\subsection{Revenue Success}

Since the high-tech startup innovation has become a cult among the college students, young innovators and people who have entrepreneurial traits [5]. Figure 1 explains the top 25 companies that received the highest number of patents according to Crunchbase downloaded database. Having a significant revenue model is the key to gain revenue success [6].

\subsection{Patents to Scale Innovation}

Filing a patent can be a tedious process in any country. But having provisional filings and invest in patenting a technology helps early-stage innovators to gain credibility. This in turn will help in gaining funds from investors and indirectly create 
a brand promise to gain the buy-in of the market. Figure 1 Shows that the patents issued to high-tech companies that were once started small. The outlier here is Apple Inc. that has significantly high revenue compared to the patents issued. This is because of the brand value conveyed to the market. In the smartphone world [7], exogenous delays in the patent examination process significantly reduce firm growth, job creation, and innovation, even when a firm's patent application is eventually approved. Our results suggest that patents act as a catalyst that sets startups on a growth path by facilitating their access to capital [8] that widens the opportunity for venture funds [9].

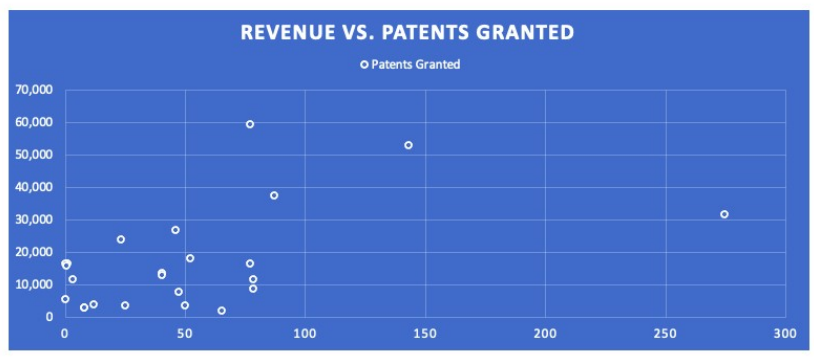

Figure 1: Revenue vs. Patents Granted for High-Tech Companies.

\section{A CASE STUDY - STARTUP FOUNDER}

Startup founder X won a business case challenge in 2014 and worked her way up for 6 years to find a team, build a product idea and generate business brand value. From observing this founder's journey, from inception to launch we can identify some successful characteristic pathways that lead to defining the cult of early-stage high-tech startup founders

The following features should be considered when defining a high-technology venture:

- High demand for scientific research and intensity of R\&D expenditure

- High level of innovativeness

- Fast diffusion of technological innovations

- Fast process of obsolescence of the prepared products and technologies

- High level of employment of scientific and technical personnel

- High capital expenditure and high rotation level of technical equipment, replaced by more modern and innovative devices

- High investment risk and fast process of the investment devaluation

- Intense, strategic domestic and international cooperation with other high technology enterprises and scientific and research centres
- Implication of technical knowledge in the form of numerous patents and licenses

- Increasing competition in international trade [1]

Founder X worked on a product-market roadmap features and with right knowledge and resources, the roadmap has to include a path towards creating high-tech startup in social media software space. This is leading towards patenting their technology and their financial roadmap meets the gold standard definition of the top 25 companies explained in Figure 1 to achieve the revenue and innovation success roadmap that they are wanting to develop a cult. Earl-stage high-tech startups follow a cult of traits, characteristics and key performance indicators like revenue and innovation credibility via patents.

\section{DERIVING FOUNDER CULT}

Finally, we are unlocking the cult of early-stage high-tech startup founders. These founders are looking for a definition, a process and qualifiers to reach high revenue success and build an innovation that are defined by registered patents.

\subsection{Derivation Itself}

The historic evidence of the revenue and patents issued says innovation builds credibility and to register that credibility, a new high-tech founder must register them as patents. More the number of patents issues, the better standing a company has along with promising revenue. Another important factor is to create a brand derived from the patent that has been issued. This is like putting the technology into use and protects a hightech startup's rights. Winning a first patent boosts a startup's subsequent growth and innovation by facilitating access to funding from venture capitalists, banks, and public investors [10]. Sections 2 and 3 explain the why.

\subsubsection{The Human Element of an Entrepreneur}

Power cues [11] are important elements of building a successful persona for an entrepreneur. It is a mindset following that humans do, it is just not about the revenue, patents or processes but a major part of the cult is the 6 power cues [11] that relates to the founder following as well.

\section{CONCLUSION}

We conclude that the early-stage high-tech startup founders must follow the characteristic traits of successful high-tech companies whose revenue is stabilized with the number of patents issued and founders themselves have a human following element using power cues of other successful founders. On the whole, this unlocks the cult of early-stage high-tech startup founders.

Future work will focus in defining the accuracy of founders hailing from various sectors covering some of the areas that is not covered in this paper. Various personality types, major challenges, and factors influencing success can be included but not limited to. 


\section{ACKNOWLEDGMENTS}

Our thanks to Crunchbase for providing a research platform to collect data and many founders who shared their in-depth experiences about their startup journey.

\section{REFERENCES}

[1] Zakrzewska-Bielawska, Agnieszka. (2010) High technology company-concept, nature, characteristics. Proceedings of the 8th WSEAS Internafional Conference on Management, Markefing and Finance, Recent Advances in Management, Markefing and Finances.

[2] Tajpour, M., Hosseini, E., and Moghaddm, A. (2018) The Effect of Managers Strategic Thinking on Opportunity Exploitation. Scholedge Int. J. Multi. Allied Stud, 5 (2): 68-81.

[3] Tajpour, M., Hosseini, E., and Salamzadeh, A. (2020) The effect of innovation components on organisational performance: case of the governorate of Golestan Province. International Journal of Public Sector Performance Management, 6 (6): 817-830.

[4] Hosseini, E., Tajpour, M., Lashkarbooluki, M. (2020) The impact of entrepreneurial skills on manager's job performance. International Journal of Human Capital in Urban Management, 5 (4): 361-372.

[5] Xinzhi, L. I. U., L. I. U. Yushan, and W. A. N. Zhuxin. (2015) Difficulties of college students' business startups under economic new normal and their countermeasures. Cross-Cultural Communication, 11 (11): 107-112.
[6] Bednar, Richard, Natalia Tariskova, and Branislav Zagorsek. (2018) Startup revenue model failures. Montenegrin Journal of Economics, 14 (4): 141-157.

[7] Gobble, MaryAnne M. (2012) Apple scores a win in the smartphone wars. Research Technology Management, 55 (6): 4.

[8] Farre-Mensa, Joan, Deepak Hegde, and Alexander Ljungqvist. (2016) The bright side of patents. No. w21959. National Bureau of Economic Research.

[9] Conti, Annamaria, Jerry Thursby, and Marie Thursby. (2013) Patents as signals for startup financing. The Journal of Industrial Economics 61 (3): 592-622.

[10] Farre-Mensa, Joan, Deepak Hegde, and Alexander Ljungqvist. (2020) What is a patent worth? Evidence from the US patent "lottery". The Journal of Finance, 75 (2): 639-682.

[11] Morgan, Nick. (2014) Power cues: The subtle science of leading groups, persuading others, and maximizing your personal impact. US: Harvard Business Press.

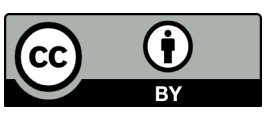

(C) 2021 by the Priyanka Botny Srinath. Submitted for possible open access publication under the terms and conditions of the Creative Commons Attribution (CC BY) license (http://creativecommons.org/licenses/by/4.0/). 